\title{
Corporate social responsibility disclosure, CEO integrity and earnings management: Evidence from the Vietnam stock market
}

\author{
Nguyen Thuy Anha*
}

${ }^{a}$ Foreign Trade University Vietnam, 91 Chua Lang, Dong Da District, Hanoi city, Vietnam

\begin{tabular}{l}
\hline C H R O N I C L E \\
\hline Article history: \\
Received June 18, 2021 \\
Received in revised format June \\
282021 \\
Accepted July 22021 \\
Available online \\
July 2 2021 \\
\hline Keywords: \\
Earnings management \\
Corporate social responsibility \\
disclosure \\
CEO Integrity
\end{tabular}

\section{Introduction}

Corporate social responsibility (CSR) disclosure has raised plenty of interest among academics, businesses and stakeholders recently. There are three main explanations for disclosing more CSR information. Firstly, companies have the greater initiative to demonstrate their concerns for society and the environment as CSR disclosure acts as a connection between a company and its stakeholders. Secondly, CSR literature provides strong evidence that CSR disclosure helps increase the value of the company (Colleoni, 2013; Michelon, 2011; Michelon, et al., 2015). However, there is also a concern relating to CSR disclosure motivation that CSR reporting acts as the greenwashing mechanism to hide the true performance of the company, which managers can do by manipulating the earnings of the companies. The third argument is that the agency problem can motivate managers to use CSR practices to hide their opportunistic behavior (Prior et al., 2008). In other words, firms involved in CSR might try to conceal the corporate misconduct activities. Therefore, the relationship between CSR disclosure and earnings management has been thoroughly investigated. Some researchers find the evidence that firms reporting their corporate social responsibility activities provide reliable and transparent information of their performance (Kim et al., 2012), which shows their commitment towards ethical and accountable behavior (Yip et al., 2011). However, some researchers believe that corporate social responsibility disclosure works as an entrenchment mechanism so that managers can gain self-interests by distorting earnings information (McWilliams et al., 2006; Choi et al., 2013). In this way, earnings management (EM) can be a productive tool for managers to disguise the true financial state of a company, especially by means of flexible accounting. Though, the empirical findings remain inconclusive whether there is a positive or negative relationship between CSR disclosure and earnings management (Sun et al., 2010; Yip et al., 2011; Muttakin et al., 2015; Belgacem \& Omri 2015; Rezaee et al., 2017).

E-mail address: nthuyanh@,ftu.edu.vn (N. T. Anh)

(C) 2022 Growing Science Ltd. All rights reserved. doi: $10.5267 / j . a c .2021 .7 .001$ 
The research in this area is commonly conducted in developed countries (e.g. Sun et al., 2010; Yip et al., 2011). However, it is noticeable that the relationship between corporate social responsibility disclosure and earnings management in developing countries has still not covered. Only a few empirical studies in developing countries, namely Belgacem and Omri (2015) in Tunisia and Muttakin et al. (2015) in Bangladesh study this topic. This gives the inspiration for studying the relationship between CSRD and earnings management in Vietnam, as a developing country.

Also, the findings of prior studies seem to be inconsistent, which could be partly explained by the measurement of corporate social responsibility disclosure. There are several methods to measure CSR disclosure. However, these methods do not provide desired effect. Some methods are not applicable in different countries while the others does not take much concern about other important dimensions of information to the right users (Muttakin et al., 2015; Belgacem and Omri 2015; Rezaee et al., 2017). This study builds a comprehensive index to measure the quality and quantity of CSR disclosure in the context of Vietnam matching with the most updated standard of CSR reporting of GRI 2016.

In the current situation, as Vietnam is integrated into the global economy, under the threats of climate changes and environmental damage, the need for a change in society's awareness towards social responsibilities is becoming more significant. CSR was firstly introduced in Vietnam in the 2000s through multinational companies investing in Vietnam, namely Honda, Coca-Cola, Unilever... These companies commonly apply the Code of Conduct and standards of business culture which cover some CSR aspects (Nguyen et al. 2015). The Vietnamese Government also started some initiatives for CSR applications such as issuing of the rule for sustainable development (new Law of Environmental Protection), Vietnam Business Linking Initiative (VBLI) to train CSR knowledge to SMEs; the project 'Helping Vietnamese SMEs adapt and adopt CSR for improved linkages with global supply chains in sustainable'... However, the role of CSR disclosure has never been focused until Circular No. 155/2015/TT-BTC issued by the Ministry of Finance was launched which requires listed companies on Vietnam's stock market to publish information on sustainable development. Most recently, in August 2019, the State Securities Commission of Vietnam introduced the first Corporate Governance Principles for listed companies, requiring the integration of CSR issues as the environment, society in the business strategy, meanwhile encouraging further disclosure and transparency of non-financial information for the investors, governing bodies and the community. As CSR disclosure becomes compulsory for listed companies, this study is inspired to investigate the level of CSR disclosure in Vietnam and its relationship with the earnings management of listed companies. Moreover, the legal and institutional framework in Vietnam is still weak with a lack of shareholder activism, poor investor protection, and poor regulatory enforcement and monitoring (World Bank 2020). Furthermore, investors have little awareness of the CSR and CSR disclosures. The disclosure by corporate is regulated by the Companies Act and the regulations of the Security Exchange Commission. All these institutional characteristics could be advantageous to managers with opportunistic behavior at the expense of minority shareholders as well as other stakeholders. A possible way of distracting stakeholders' attention could be engaging in some CSR activities. In this way managers in Vietnamese firms could use CSR disclosure practices to manipulate earnings.

The paper's objectives are to study the level of CSR disclosure of listed companies in Vietnam by using index measurement method, to investigate its relationship with earnings management in Vietnam to further study the motivations of CSRD in Vietnam, and to evaluate the role of CEO in earnings management, therefore propose some practical implications for policymakers and managers in Vietnam.

The paper contributes to the literature in two aspects. The first contribution is the impact of CSR reporting on earnings management. The previous studies in this area explore the impact mostly in developed countries but those in developing countries have been little investigated. Our second contribution is the determinants of earnings management. Most available research in this area focused on company characteristics. Little study has yet empirically examined the role of CEO integrity on earnings management. Our findings should be of interest to investors for decision-making in investment in stock markets.

The remainder of this paper is as follows: Section two discusses the literature review and develops the hypotheses. Section three sets out the study's methodology and discusses sample selection and model specification. Section four presents the results and Section five summarizes the major themes covered and the conclusion.

\section{Literature review and hypothesis development}

\subsection{Corporate social responsibility (CSR)}

Corporate social responsibility (CSR) arises from an era where awareness of the long-term sustainability of the company is put more weight than profitability. According to Ward (2004), CSR is a commitment of businesses to contribute to sustainable economic development to improve the quality of life, in other words, what is good for business is good for the community too. Meanwhile, according to ISO 26000, social responsibility is the wish of an organization to deal with the social and environmental aspects in decision making and is accountable for the impact of their decisions and activities on the society and environment. In general, the authors support the definition of CSR as being the way how a corporation makes a balance of economic, environmental, and social aspects, in order to satisfy the expectations of stakeholders.

\subsection{CSR Disclosure}

From the 1960 s to the $1980 \mathrm{~s}$, as investors increasingly concerned about business operation affection towards the environment, managers began to come up with methods to deal with such environmental and social issues (Brown et al., 
2009). When shareholders look forward to corporate social responsibility disclosure performance, especially those related to the society and environment (Cornelissen, 2008), companies and managers start to disclose their corporate social responsibility information (Schaltegger et al., 2006; Carroll, 2008). During the 1990s, the act of corporate social responsibility disclosure, which was considered as "a marketing process for the affection of economic organizations to the society, the environment and groups of special interest in the society" (Gray et al., 1963) gradually became more popular. In the late 1990s, Union of Economies for the Environment (CERES) developed the Global Reporting Initiatives (GRI), which nowadays has been commonly used all over the world.

Recent studies have shown that transparency in corporate social responsibility brings about a lot of benefits. Cheng (2014) and Cheng et al. (2014), together with Ioannou and Serafeim (2015) argue that companies with better corporate social responsibility transparency will have fewer constraints in accessing capital and finance. Dhaliwal et al. (2011) point out that companies experience a reduction in the cost of equity after issuing corporate social responsibility reports. The release of corporate social responsibility reports is associated with a lower analytical forecast error. Referring to Brammer and Pavelin (2008), corporate social responsibility disclosure concerning the environment would result in less legislative pressure and more future economic benefits.

\subsection{Earnings management}

According to Scott (2006), earnings management is defined as the selection of accounting policies by the manager which can maximize their utility and/or the market value of the company. The other way of defining earnings management is the manipulation of earnings, both inside and outside the boundaries of accepted accounting principles generally (Dechow et al., 1995, Murwaningsari 2008), so earnings management and earnings manipulation can be used changeably. However, earnings management is not completely the same as manipulation. Earnings management is done by the management by exploiting the inherent weaknesses of the accounting policies, whereas earnings manipulation violates accounting principles to produce the company's financial results. Therefore, it can be concluded that earnings management is an action by the management of the company on the financial reporting process to influence the decisions of users as well as for the interest of managers.

\subsection{Effect of CSR disclosure on earnings management}

Relating to the impact of CSR disclosure on earnings management, there are two contradicting arguments. Some researchers find that there is a negative impact of CSR disclosure on earnings management. Wang et al. (2016) investigate the relationship between mandatory CSR disclosure and earnings management and conclude that CSR disclosure reduces information asymmetry by providing more relevant information to the stakeholders and by increasing public attention. With less information asymmetry, EM is less likely to be favored. These findings illustrate the negative relationship between EM and CSR disclosure. Besides, Yip et al. (2011) extend to investigate the relationship between EM and voluntary CSR disclosure and how the relationship is affected by the contextual factors, namely the political costs. The study is based on a sample of US firms and shows a more complicated relationship: for firms suffering higher political costs, more CSR disclosure leads to lower EM, but for firms with lower political costs, more CSR disclosure increases EM.

Relating to the attributes of earnings management, Laksmana and Yang (2009) examine the connection between corporate citizenship (a substitute term of CSR) and earnings management. They show that for firms with better CSR disclosures, the earnings are more predictable, more persistent, and smoother than those with worse CSR reporting. Similarly, Choi and Pae (2011) find that firms that commit ethically to the community report earnings more conservatively and estimate the cashflow more accurately. Moreover, Kim et al. (2012) find that socially responsible firms are less likely to engage in manipulating operating activities and less likely to be under the scrutiny of governmental agencies. Their findings are consistent with the legitimacy theory as CSR-related factors may drive managers to issue high-quality financial reports.

These arguments come to the following hypothesis:

Hypothesis 1a: Firms with more CSR disclosure are less likely to engage in earnings management.

Otherwise, there is a contradicting hypothesis, namely the positive relationship between CSR disclosure and EM. The positive relationship can be explained as the opportunistic use of CSR disclosure because it can help managers improve firms' reputation and legitimacy. Prior et al. (2008) illustrate a positive relationship between EM and CSR performance with a multinational sample, in which, CSR is used to steer the stakeholders' attention away from EM activities. Haryudanto and Yuyetta (2011) believe that managers in companies having earnings management activities tend to issue more CSR policies to improve their image and gain more support from the public and stakeholders.

The positive relationship can be explained by the agency theory as managers can use CSR practices to pursue their own interests (Jensen and Meckling, 1976). Besides, under legitimacy theory, CSR can be a tool to deal with legitimate threats (Deegan, 2002). Martínez-Ferrer et al. (2016) state that CSR is often used as a "strategic shield" against the unexpected consequences of EM. The authors argue that CSR makes a positive impact on the firm reputation and the cost of funding, which can offset the negative impact of EM. Specifically, the market fails to detect EM when CSR is employed as a technique to cover it. Salewski and Zulch (2012), based on a sample of 258 firms in 10 developed countries find that firms with a higher level of CSR are more likely to engage in earnings management and report negative news in a less timely manner. Chakravarthy et al. (2014) share this view when they state that CSR is an action of reputation-building for firms 
with earnings restatements in previous years. To explain the mechanism of this impact more clearly, Guiral (2012) shows that positive CSR activities can improve auditors' perceptions of control systems. Hence, our second hypothesis reads:

Hypothesis 1b: Firms with more CSR disclosure are more likely to engage in earnings management.

\subsection{Role of CEO Integrity}

According to agency theory by Jensen and Meckling (1976) and Jensen (1986), the manipulations are beneficial for the managers and allow them to improve their position at the cost of other stakeholders. Therefore, the association between a CEO's attitudes and a firm's earnings management is worth researching. In extensive reviews of the literature on integrity, Audi and Murphy (2006), Palanski and Yammarino (2007), and Bauman (2013) summarized many faces of integrity of which are widely cited as critical moral characteristics. Pham and Tran (2020) define CEO integrity as the CEO's quality of being honest, fidelity, and moral courage. Therefore, based on Agency theory, we believe that CEO integrity has an impact on the earnings management of firms. These above arguments lead to the second hypothesis:

Hypothesis 2: Firms with higher CEO Integrity are less likely to engage in earnings management.

\section{Research methodology}

\subsection{Data and research sample}

We select a sample of listed firms on the Hochiminh stock exchange and the Hanoi stock exchange. Firstly, we pick up listed companies with full financial data from 2014-2018. Then we screen the list, keeping the firms disclosing the full annual report and/or CSR reports during 2014-2018. For data on financial performance and corporate governance, we collect from FinPro and Vietstock databases. For CSR reporting, we manually collect from the annual reports and/or CSR reports of listed firms. After deleting observations with missing data, we have the final balanced dataset of 750 firm-year observations from 150 firms in 8 industries classified by ICB (Industry Classification Benchmark) developed by FTSE Group and DowJones during 2014-2018.

For scoring the CSR disclosure of listed firms, we perform the trial grading of 8 listed companies in 8 industries to evaluate the reliability and credibility of the CSR disclosure index as well as assure a consistent understanding of the surveyor teams. We correct some explanations in the survey forms, then finally, we perform the whole sample to score the CSRD index. After grading the whole sample, we cross-check the results to make sure of the reliability of the index.

\subsection{Empirical model}

To test hypotheses 1a, 1b, and 2, we use model (1) in which Earnings management is the dependent variable, while CSR disclosure and CEOIntegrity are the key independent indicators. We also include control variables due to their potential effects on earnings management, as described later.

$$
E M_{i t}=\alpha_{1} \text { CSRD }_{i t}+\alpha_{2} \text { CEOInterity }_{i t}+\alpha_{i} \text { Control variables }_{i t}+\varepsilon_{i t}
$$

(Model 1)

\subsection{CSR variables}

The quality of information disclosure can be measured in various ways, depending on the complexity and multi-dimensional approach. According to Hassan and Marston (2019), it is difficult to observe and measure directly the act of disclosing information, which therefore is considered as a latent variable. Hassan and Marston (2019) point out the three most-used evaluation methods for corporate information disclosure quality. The first one is the classification approach which "involves sorting observations into mutually exclusive groups according to an aspect of corporate financial disclosure that is being studied". The items observed can be broad as a disclosure policy or a reporting regime or narrow such as a specific disclosure item. Even though this method is flexible, relatively time-efficient to collect and code, and can be used for large-scale samples, it cannot capture differences in the dimension of disclosure among companies that belong to the same group. In addition, as the coding could be subjective, hence results could be difficult to replicate, compare, and generalize. The second method is the disclosure index, which is used to assess the extent of the information reported on a disclosure vehicle. The items of information could be quantitative or qualitative or both. However, the assignment of weights may have problems due to concept and procedure issues (Dhaliwal, 1980; Cooke and Wallace, 1989; Hodgdon et al., 2009; Cheung et al., 2010). This is one of the most popular measures of disclosure; it is used in a variety of contexts indicating how flexible the method is. In the third place, the word counting method can quantify the number of distinctive disclosures without evaluating their content or context. Even this method is relatively time-efficient to collect and code and can be used to study large-scale samples but it could also be induced by other managerial incentives such as management reputation and cannot take account of the quality of the information disclosed.

Among the above most popular methods, Marston and Shrives (1991) support the disclosure index in which all component information within the disclosure index can be either voluntary or mandatory, either financial or non-financial. Hassan (2019) also shares the same viewpoint as Marston and Shrives (1991), claiming that the use of disclosure index is to serve the purpose of evaluating the level of reported information with the help of a specific entity, which actually bases on a list of selected items of information. Healy and Palepu (2001) also list out benefits of self-compiled indexes. This is the reason why the author chooses the index method to measure CSR disclosure. 
Based on two information disclosure indices, including the environmental disclosure index by Clarkson et al. (2008) and the sustainability disclosure information index by Ong (2016), the authors adjust and construct the disclosure index of Vietnam listed companies. According to Clarkson et al. (2008), the environmental disclosure index sets the base of guidelines for the preparation of sustainability reports issued by GRI in 2002 (or also known as G2) to measure the level of environmental disclosure of companies. This index is the basis for many subsequent studies, such as Sutantoputra (2009), Ong et al. (2016). Ong et al. (2016) integrated the fundamental principles of the hard and soft disclosure items of environmental index Clarkson et al. (2008) with the social and economic aspects of the GRI framework of 2006 to measure the level of disclosure on the sustainable development of Australian resources industry.

This study used the latest set of GRI standards issued in 2016 to develop the CRSD Index. The borderline between the mandatory and voluntary can be changeable by times, hence following GRI standards, we divide the information disclosed by contents as follows: (1) Information disclosed on governance structure; (2) Information disclosed of the vision, the strategic commitment of managers, and management mechanisms in the enterprise; (3) The reliability of the report; (4) Information disclosed of CSR outcome indicators on the economy, environment, and society.

\section{Table 1}

The CSR disclosure index

\begin{tabular}{lll}
\hline Code & Criteria & Grading explanation \\
\hline A1 & Management structure & Maximum of 6 points \\
A2 & Vision, Strategy claims & Maximum of 6 points \\
A3 & Credibility & Maximum of 6 points \\
A4.ECP & Economic performance indicators (ECP) & Maximum of 12 points \\
A4. ENP & Environmental performance indicators (ENP) & Maximum of 32 points \\
A4.SPI-LAP & Social performance indicators - Labor Practice and Decent Work (SPI-LAP) & Maximum of 20 points \\
A4.SPI-HRP & Social performance indicators - Human Rights (SPI-HRP) & Maximum of 20 points \\
A4.SPI-SOP & Social performance indicators - Society (SPI-SOP) & Maximum of 24 points \\
A4.SPI-PRP & Social performance indicators - Product (SPI-PRP) & Maximum of 16 points \\
\hline
\end{tabular}

Within the first three sections (A1 to A3), the rating system goes that 1 is scored if a firm mentions information specified and 0 is given if that information is not disclosed. Section A4 uses a different scale to markup disclosure in corporate social responsibility. Each criterion will be marked from 0 to 4, with 0 equal to non-given information, 1 means that information is mentioned, 2 is equal to detailed information, 3 is equivalent to the fact that information was compared and evaluated and 4 means that enterprise can provide the targets for next year. In this way, CSR quality and quantity disclosure can be incorporated in CSRD Index, which is measured as follows:

CSRD Index $=(\text { Scored points/Maximum points })^{*} 100 \%$

\subsection{Measurement of Accrual Earnings management}

To measure the accrual earnings management quality, we use the modification of the Jones (1991) model to adjust for the possibility that revenues are manipulated, performed by removing changes in net receivables from the model, since it is easier to exercise discretion over revenue recognition for credit sales, compared to cash sales (Dechow et al., 1995). Under this model, the extent of discretionary accruals for a specific firm is measured as the difference between the firm's total accruals and its non-discretionary accruals (NDAC), as estimated by model 2:

$$
T A C_{i t} / T A_{i t-1}=\alpha_{1}\left(1 / T A_{i t-1}\right)+\alpha_{2}\left(\left(\Delta R E V_{i t}-\Delta R E C_{i t}\right) / T A_{i t-1}\right)+\alpha_{3}\left(P P E_{i t} / T A_{i t-1}\right)+\varepsilon_{i t}
$$

(Model 2)

where:

$\Delta R e v=$ Sales in year $\mathrm{t}$ minus sales in year $t-1$, scaled by lagged total assets;

$\Delta R e c=$ receivables in year $\mathrm{t}$ minus net receivables in year $\mathrm{t}-1$, scaled by lagged total assets;

$P P E=$ net property, plant and equipment, scaled by lagged total assets;

$T A_{t-1}=$ Total Asset in year $\mathrm{t}-1$

For $T A C_{i t}$ (total accruals), we use the cash-flow approach to estimate total accruals (Jones \& Hensher, 2007; Hribar $\&$ Collins, 2002). This approach involves deducting the cash flow from operations obtained from the statement of cash flows from the amount of income (before extraordinary items) from the income statement.

$T A C_{i t}=N I_{i t}-C F O_{i t}$

Using the coefficient estimates obtained from Model (2), we calculate the level of normal discretionary accruals $\left(N D A C_{i t}\right)$ as a percent of lagged total assets.

$N D A C_{i t}=\alpha_{1} \times\left(1 / T A_{i t}-1\right)+\alpha_{2} \times\left(\Delta R E V_{i t}-\Delta R E C_{i t}\right) / T A_{i t-1}+\alpha_{3} \times P P E_{i t} / T A_{i t-1}$

Finally, we measure Discretionary Accruals $\left(D A_{i t}\right)$ as the difference between TAC and NDAC as follows:

$D A_{i t}=\left(T A C C_{i t} / T A_{i t-1}\right)-N D A C_{i t}$ 
We get the absolute value of DA. The higher DA, the more manipulation is made.

\subsection{Measurement of CEO Integrity}

Due to limited data access, we apply the model of measuring CEO integrity by Pham and Tran (2020). Management efficiency can be determined by the capability and integrity of the CEO, internal governance (e.g. board independence), and external control (e.g. a nation's auditing and reporting standards). The management efficiency can be seen as a function of the interaction effect among CEO integrity, board independence, and a nation's auditing and reporting standards. The CEO integrity can be measured as follows:

CEO integrity $=$ Management efficiency/(Board independence $\times$ Strength of auditing and reporting standard)

As the strength of auditing and reporting standards is the same in one country, so CEO integrity can be proxied by the ratio of management efficiency divided by board independence. Management efficiency can be measured by the asset turnover of firms (Sales/Total assets) and board independence can be measured by the number of independent board members.

\subsection{Control Variables}

We incorporate several control variables in our model.

Firm size

We control for firm size as it can explain the fluctuation in EM (Roychowdhury (2006). It can be measured the natural $\log$ of total assets.

\section{Capital structure}

Financial leverage, measured by debt/total assets can be a consideration for managers to manage earnings (Press and Weintrop, 1990). Francis et al. (2004) state that firms using more external funds tend to assure a higher quality of financial statement as it can reduce the cost of borrowing. In contrast, Sweeney (1994), Dichev and Skinner (2002) and Bharath et al. (2008) believe that managers are motivated to manage earnings more to avoid the penalties of debt covenants.

Growth

We control for sales growth because according to Skinner and Sloan (2002), growing firms have stronger incentives to meet earnings targets. It is counted as the sales increase in percentage from year $\mathrm{t}-1$ to year $\mathrm{t}$ (Yip et al., 2011).

Loss

Firms with negative earnings are linked with greater discretionary accruals (Wang, 2006). So, we use a dummy variable equal to " 1 " when a firm has negative earnings before extraordinary in a particular year and otherwise " 0 ".

Audit

Prior research suggests that big-name auditing firms (Big 4) are more effective to investigate financial reporting than smaller firms (Francis, 2004; Francis and Krishnan, 1999). Hence, we use a dummy variable equals to 1 (Big 4 ) and otherwise 0 to control for the effect of audit firm type on discretionary accruals.

\section{Board size}

Agrawal and Cooper (2016) document that bigger size of the board leading to sluggish communication and Jensen (1993) argues that communication of a larger board size can be a bottleneck to effective board oversight of the management behaviors, so these facts can increase the earnings management. However, other researchers, namely Coles et al. (2006), Pearce and Zahara (1992) document that bigger board size results in higher independent board members or Dalton et al. (1999) state that expertise and enhanced knowledge of board members in larger board size can improve the supervision of management in terms and these facts can deter earnings management.

Independent board members

According to agency theory, outside directors can increase the board's independence from management. Klein (2002) has evidence supporting that independent outside director can constrain earnings management.

CEO duality

Firms with CEO duality perform less efficiently than their competitors (Abdul Rahman \& Haniffa, 2005). However, other authors do not find any significant relation between CEO duality and earnings management (Cornett et al., 2008; García-Meca \& Sánchez-Ballesta, 2009).

\section{Concentrated ownership}

Agency theory states that managers in less concentrated ownership may have more incentives to manipulate the financial results to get more earnings-based bonuses and less pressure from stakeholders. Shleifer and Vishny (1997) 
show that concentrated or block ownership can increase the effectiveness of board monitoring as it can constrain opportunistic behavior. Hence, discretionary accruals are negatively linked with concentrated ownership (Warfield et al, 1995).

In this model, we use two control variables for concentrated ownership. The first factor is state ownership. Guo and Ma (2015) result is supported by a decrease in earnings management when the central government acts as the principal shareholder. The second one is foreign ownership. Chung et al. (2004) find that foreign owners in Japan can constrain managerial opportunism and lower discretionary accruals for profit firms. However, Dvorak (2005) documents that domestic investors in Indonesian market earn higher profits than foreign investors as the distance makes it difficult for foreign investors to monitor the managers' behaviors.

\subsection{Methodology}

Firstly, to check the reliability of the disclosure index, we use Cronbach's Alpha. Carmines and Zeller (1991) define Cronbach's alpha as 'an estimate of the expected correlation between one test and a hypothetical alternative form containing an equivalent number of items'. It reflects the homogeneity among a variety of things grouped together to make a specific scale. It shows how well the various items complement one another in their measurement of various aspects of an equivalent variable (Fink \& Litwin, 1995). It can take values from zero to one. The higher the coefficient alpha obtained, the higher the reliability of the size. It takes the utmost value of 1 when the correlation between each pair of things is one. A general accepted rule is that the value of 0.6-0.7 indicates an acceptable level of reliability, and 0.8 or greater a very good level (Carmines and Zeller, 1991). Botosan (1997) and Hassan et al. (2009) used this technique as a measure of the internal consistency of their measures of disclosure. Additionally, Botosan (1997), Kelton and Yang (2008) measured the correlations among the components (categories) of a disclosure index.

Second, we perform descriptive statistics analysis and correlation analysis to check characteristics about mean, maximum and minimum values of variables as well as termite correlations between variables within the model. We also check the multicollinearity problem by examining the correlation coefficients of every pair of the predictors and their Variance Inflation Factor (VIF).

On that basis, we estimate Model (1) using EM (measuring accrual earnings) and because of the dependent variable with fixed effect model and random effect model. To work out which model is more appropriate, we still use the Hausman test. We also run the tests for serial correlation and potential endogeneity of our key predictors (CSRD) and find that the model incurs those phenomena. To mitigate the endogeneity problem of CSRD in case of a loop of causality between the independent and dependent variables, we use the GMM model and use the results.

\section{Results}

The result of the overall alpha is $(0.8158)$ greater than 0.6 , however, consistent with item-rest correlation, A1 (management structure) is (0.282) smaller than 0.8. Therefore, the A1 score is removed from the CSRD score. After removing A1, we run the Cronbach's Alpha for a second time, and therefore the overall alpha is 0.8256 greater than 0.8 and there is no item-rest correlation smaller than 0.4 , which indicates that CSRD estimation is reliable and internally consistent.

The descriptive statistics of our dataset are presented in Fig. 1. Regarding the firm size (total asset), the mean average total asset is 141,000 VND billion (equivalent to USD 5.8 million). The CSRD mean average value is 14\% with the utmost value is $44 \%$ and min value adequate to 0 , which suggests a rather low level of CSR disclosure of listed firms in Vietnam. The definite quantity of EM is 0.632 of average. On average, $59 \%$ of our firms are audited by the Big- 4 accounting firms. The foreign investor holds about $8 \%$ of the shares outstanding and the state holds a mean of $17 \%$. The typical percentage of independent directors on the board is $68 \%$. We also find that $24 \%$ of our sample firms have a CEO who also is the Chair of the board (CeoDual). Among the entire sample, only 3.87\% firm suffers loss within the current year.

All of the VIFs are smaller than 5, which is far smaller than the threshold of 10, suggesting that multicollinearity isn't a problem with our dataset (Mansfield and Helms, 1982).

Table 2

The descriptive statistics for the variables

\begin{tabular}{|c|c|c|c|c|c|}
\hline VarName & Obs & SD & Mean & Min & Max \\
\hline EM & 750 & 0.782 & 0.632 & 0.000 & 7.492 \\
\hline CSRD & 750 & 0.0744 & 0.1391 & 0 & 0.4435 \\
\hline SIZE (VNĐ billion) & 750 & 38,200 & 141,000 & 53.9 & $1,310,000$ \\
\hline Boardsize & 750 & 1.616 & 6.127 & 3.000 & 15.000 \\
\hline GROWTH & 750 & 1.944 & 1.290 & 0.000 & 41.767 \\
\hline LEV & 750 & 0.226 & 0.584 & 0.015 & 0.993 \\
\hline CEODu & 750 & 0.427 & 0.240 & 0.000 & 1.000 \\
\hline IBM & 750 & 0.1847 & 0.6814 & 0.000 & 1.000 \\
\hline Audit & 750 & 0.493 & 0.588 & 0.000 & 1.000 \\
\hline FO & 750 & 12.249 & 7.723 & 0.000 & 73.810 \\
\hline SO & 750 & 26.840 & 17.025 & 0.000 & 95.760 \\
\hline Loss & 750 & 0.193 & 0.039 & 0.000 & 1.000 \\
\hline CEOIntegrity & 750 & 0.257 & 0.240 & 0.000 & 1.916 \\
\hline
\end{tabular}


Table 3

The distribution of CEODu, Audit and Loss variable in the sample

\begin{tabular}{llll}
\hline & Value & Freq. & Percent \\
\hline CEODu & 0 & 569 & 75.87 \\
& 1 & 181 & 24.13 \\
\hline Audit & 0 & 311 & 41.47 \\
& 1 & 439 & 58.53 \\
\hline Loss & 0 & 721 & 96.13 \\
& 1 & 29 & 3.87 \\
\hline & Total & 750 & 100 \\
\hline
\end{tabular}

Relating to the distribution of industries, among 150 firms, the largest proportion is industrials (33\%), the others industries including materials, consumer goods, financials are the same proportion of $14-17 \%$, the rest groups including technology, health care, utilities account the same stake ranging from $2-7 \%$.

Table 4

The distribution of industries in the sample

\begin{tabular}{llll}
\hline Industry & Freq. & Percent & Cum. \\
\hline Materials & 21 & 14 & 14 \\
Consumer Goods & 21 & 14 & 28 \\
Financials & 26 & 17.33 & 45.33 \\
Technology & 3 & 2 & 47.33 \\
Consumer Services & 11 & 7.33 & 54.67 \\
Health care & 9 & 6 & 60.67 \\
Utilities & 10 & 6.67 & 67.33 \\
Industrials & 49 & 32.67 & 100 \\
\hline Total & 150 & 100 & \\
\hline
\end{tabular}

As mentioned on Methodology section, we run the model (1) using DA (measuring accrual earnings) and as the dependent variable with fixed effect model and random effect model. However, the test results show that, the model has problems of serial correlation and endogeneity. Then we run the GMM model and use the results for discussion.

Table 5

Regression results

\begin{tabular}{|c|c|c|c|}
\hline EM & $\begin{array}{l}\text { (1) } \\
\text { FEM }\end{array}$ & $\begin{array}{l}\text { (2) } \\
\text { REM }\end{array}$ & $\begin{array}{l}\text { (3) } \\
\text { GMM }\end{array}$ \\
\hline $\mathrm{EM}_{\mathrm{t}-1}$ & & & $\begin{array}{l}0.525 * * * \\
(0.0388)\end{array}$ \\
\hline CSRD & $\begin{array}{l}0.00290 \\
(0.00450)\end{array}$ & $\begin{array}{l}0.00170 \\
(0.00356)\end{array}$ & $\begin{array}{l}0.00486 * * \\
(0.00238)\end{array}$ \\
\hline SIZE & $\begin{array}{l}-0.124 \\
(0.0813)\end{array}$ & $\begin{array}{l}-0.104 * * \\
(0.0491)\end{array}$ & $\begin{array}{l}-0.0542 * * \\
(0.0257)\end{array}$ \\
\hline Boardsize & $\begin{array}{l}-0.0363 \\
(0.0562)\end{array}$ & $\begin{array}{l}0.000558 \\
(0.0397)\end{array}$ & $\begin{array}{l}0.0447 * * \\
(0.0217)\end{array}$ \\
\hline GROWTH & $\begin{array}{l}0.0681 * * * \\
(0.0127)\end{array}$ & $\begin{array}{l}0.0667 * * * \\
(0.0122)\end{array}$ & $\begin{array}{l}0.0344 \\
(0.0280)\end{array}$ \\
\hline LEV & $\begin{array}{l}-0.417 \\
(0.359)\end{array}$ & $\begin{array}{l}-0.228 \\
(0.225)\end{array}$ & $\begin{array}{l}0.123 \\
(0.111)\end{array}$ \\
\hline CEODu & $\begin{array}{l}-0.0349 \\
(0.105)\end{array}$ & $\begin{array}{l}-0.168^{*} \\
(0.0870)\end{array}$ & $\begin{array}{l}-0.123 * * * \\
(0.0414)\end{array}$ \\
\hline IBM & $\begin{array}{l}0.3355 \\
(0.0525)\end{array}$ & $\begin{array}{l}0.1834 \\
(0.0396)\end{array}$ & $\begin{array}{l}-0.0170 \\
(0.0220)\end{array}$ \\
\hline Audit & $\begin{array}{l}0.0104 \\
(0.134)\end{array}$ & $\begin{array}{l}-0.0733 \\
(0.0894)\end{array}$ & $\begin{array}{l}-0.0138 \\
(0.0410)\end{array}$ \\
\hline FO & $\begin{array}{l}0.000558 \\
(0.00431)\end{array}$ & $\begin{array}{l}-0.00461 \\
(0.00321)\end{array}$ & $\begin{array}{l}-0.00200 \\
(0.00166)\end{array}$ \\
\hline $\mathrm{SO}$ & $\begin{array}{l}-0.000300 \\
(0.00279)\end{array}$ & $\begin{array}{l}0.00567 * * * \\
(0.00174)\end{array}$ & $\begin{array}{l}0.00374 * * * \\
(0.000977)\end{array}$ \\
\hline Loss & $\begin{array}{l}0.126 \\
(0.128)\end{array}$ & $\begin{array}{l}0.120 \\
(0.122)\end{array}$ & $\begin{array}{l}0.149 * * * \\
(0.0461)\end{array}$ \\
\hline CEOIntegrity & $\begin{array}{l}-0.319 \\
(0.256)\end{array}$ & $\begin{array}{l}-0.307^{*} \\
(0.185)\end{array}$ & $\begin{array}{l}-0.316 * * * \\
(0.0965)\end{array}$ \\
\hline Constant & $\begin{array}{l}4.444 * \\
(2.272)\end{array}$ & $\begin{array}{l}3.686^{* * *} \\
(1.352)\end{array}$ & $\begin{array}{l}1.581 * * \\
(0.686)\end{array}$ \\
\hline Observations & 520 & 520 & 520 \\
\hline R-squared & 0.116 & & \\
\hline Number of $\mathrm{i}$ & 134 & 134 & 134 \\
\hline Autocorraltion test & 0.0055 & & \\
\hline Heteroskedasticy test & 0.0000 & & \\
\hline $\operatorname{AR}(2)$ & & & 0.087 \\
\hline Hansen test & & & 0.476 \\
\hline
\end{tabular}

$* * * \mathrm{p}<0.01,{ }^{* *} \mathrm{p}<0.05,{ }^{*} \mathrm{p}<0.1$ 
The GMM estimation results of Model (1) are demonstrated in Table 2 using EM measured by Accrual earnings. As it can be seen, CSR disclosure is significantly and positively associated with $\operatorname{EM}(\beta=0.00486)$ at the significance level of $5 \%$. CEO integrity also is negatively associated with EM $(\beta=-0.316)$ with a significance level of $1 \%$. Therefore, our hypotheses of $1 \mathrm{~b}$ and 2 are confirmed. Firms with a higher level of CSR are more likely to engage in earnings management, in this way managers use CSR disclosure as a shield to manipulate more. However, the CEO's integrity could be an important factor to decrease earnings management.

Among other control variables, the results show that Board size, State ownership (SO) and Loss are significantly and positively associated with EM, at the respective coefficients of 0.0447 (5\% significance), 0.00374 (1\% significance), and 0.149 (1\% significance).

For Board size, the results are congruent with Agrawal and Cooper (2016) that bigger size of the board leading to sluggish communication then increases the earnings management. Relating State ownership, as the controlling shareholder and the regulator, are government agencies, it is more difficult to implement effective checks and balances, so the manipulation is higher. For Loss results, firms with negative earnings are associated with greater discretionary accruals, which is supported by Wang (2006).

Regarding firm size, the negative coefficient shows that the bigger size the firm is, the fewer earnings management is made. This is congruent with Wang et al. (2016) and Martínez-Ferrero et al. (2016). However, for CEO duality, even though some of the research shows a positive relationship with EM, the results of this paper find the opposite relationship. This can be explained by stewardship theory. It is stated that one person in dual positions may improve firm performance, removing any internal and external ambiguity concerning responsibility for stable processes and upshots (Dulewicz and Herbert, 2004), in this way reduce the earnings manipulation.

\section{Discussion and conclusion}

The results of our estimation models account for the impact of CSR disclosure and CEO Integrity on earnings management. Many prior studies assume a direct impact of CSR disclosure on earnings management; however, their findings are inconclusive. Our results are in line with Prior et al. (2008), Chakravarthy et al. (2014) Martínez-Ferrer et al. (2016), which confirm that companies with more CSR disclosure can involve more in earnings management. This fact can be explained that in developing countries like Vietnam, where the legal system is not mature yet and the enforcement system is weak, managers have a higher incentive of disclosing CSR information and using it to cover the earnings manipulation. Therefore, investors should take more consideration for the firms disclosing more CSR.

Moreover, the results add further insight into the role of CEO integrity EM and CEO integrity where CEO Integrity can help deter the EM. Even though there are some papers studying the link between CEO Integrity and firm performance (Pham and Tran, 2020) or the link between CEO characteristics and firm performance (Saidu, 2019), there is no specific paper examining the impact of a leader's integrity on earnings management before.

In this way, our paper makes several contributions to the literature. First, this study extends previous research by providing a more comprehensive view and strong evidence about the relationship between CSR disclosure and earnings management. We believe our findings provide robust evidence that companies especially in developing countries disclose more CSR information in order to make more manipulation of earnings. Second, our paper robustly builds an index to measure the CSR disclosure for listed firms, not only accounting for the completeness and up-to-dateness but also the credibility and the quality of information disclosure. Third, our paper is among the first, which proves the evidence of the significant role of a leader's integrity in driving earnings management. In this way, we suggest that enhancing CEO Integrity could be a productive way to control the earnings management inside the companies.

The limitation of this research is associated with the proxy of CEO integrity due to the limited access to data. We suggest the measurement of CEO integrity takes more account of individual aspects of the CEO. Furthermore, we will consider the moderating role of CEO integrity when examining the effects of strategies and decisions made by a firm's top management of firms' earnings management.

\section{Acknowledgement}

The paper is sponsored by MOET of Vietnam, under the research project "CSR Information Transparency of listed firms in Vietnam", code: B2019-NTH-08

\section{References}

Agrawal, A., \& Cooper, T. (2017). Corporate governance consequences of accounting scandals: Evidence from top management, CFO and auditor turnover. Quarterly Journal of Finance, 7(01), 1650014.

Audi, R., \& Murphy, P. E. (2006). The many faces of integrity. Business Ethics Quarterly, 3-21.

Bauman, D. C. (2013). Leadership and the three faces of integrity. The leadership quarterly, 24(3), 414-426.

Belgacem, I., \& Omri, A. (2015). Does corporate social disclosure affect earnings quality? Empirical evidence from Tunisia. International Journal, 3(2), 73-89.

Bharath, S. T., Sunder, J., \& Sunder, S. V. (2008). Accounting quality and debt contracting. The Accounting Review, 83(1), $1-28$. 
Brammer, S., \& Pavelin, S. (2008). Factors influencing the quality of corporate environmental disclosure. Business strategy and the environment, 17(2), 120-136.

Brickley, J. A., \& James, C. M. (1987). The takeover market, corporate board composition, and ownership structure: The case of banking. The Journal of law and economics, 30(1), 161-180.

Brown, H. S., de Jong, M., \& Levy, D. L. (2009). Building institutions based on information disclosure: lessons from GRI's sustainability reporting. Journal of cleaner production, 17(6), 571-580.

Carmines, E. G., \& Zeller, R. A. (1979). Reliability and validity assessment. Sage publications.

Carroll, A. B. (2008). A history of corporate social responsibility: Concepts and practices. The Oxford handbook of corporate social responsibility, 1 .

Chakravarthy, J., DeHaan, E., \& Rajgopal, S. (2014). Reputation repair after a serious restatement. The Accounting Review, 89(4), 1329-1363.

Cheng, Q. (2014). Family firm research-A review. China Journal of Accounting Research, 7(3), 149-163.

Cheng, B., Ioannou, I. \& Serafeim, G. (2014). Corporate social responsibility and access to finance. Strategic Management Journal, 35 (1), 1-23.

Choi, T. H., \& Pae, J. (2011). Business ethics and financial reporting quality: Evidence from Korea. Journal of Business Ethics, 103(3), 403-427.

Chung, R., Ho, S., \& Kim, J. B. (2004). Ownership structure and the pricing of discretionary accruals in Japan. Journal of International Accounting, Auditing and Taxation, 13(1), 1-20.

Clarkson, P. M., Li, Y., Richardson, G. D., \& Vasvari, F. P. (2008). Revisiting the relation between environmental performance and environmental disclosure: An empirical analysis. Accounting, Organizations and Society, 33(4-5), 303-327.

Coles, J. L., Daniel, N. D., \& Naveen, L. (2006). Managerial incentives and risk-taking. Journal of financial Economics, 79(2), 431-468.

Colleoni, E. (2013). CSR communication strategies for organizational legitimacy in social media. Corporate Communications: An International Journal, 18(2), 228-248.

Cornelissen, J. P. (2008). Corporate communication. The International Encyclopedia of Communication.

Cornett, M. M., Marcus, A. J., \& Tehranian, H. (2008). Corporate governance and pay-for-performance: The impact of earnings management. Journal of financial economics, 87(2), 357-373.

Dalton, D. R., Daily, C. M., Johnson, J. L., \& Ellstrand, A. E. (1999). Number of directors and financial performance: A meta-analysis. Academy of Management journal, 42(6), 674-686.

Dechow, P., Sloan, R. \& Sweeney, A. (1995). Detecting EM. The Accounting Review, 70, 93-225.

Deegan, C. (2002). Introduction: The legitimising effect of social and environmental disclosures-a theoretical foundation. Accounting, Auditing \& Accountability Journal, 15(3).

Dhaliwal, D. S., Li, O. Z., Tsang, A., \& Yang, Y. G. (2011). Voluntary nonfinancial disclosure and the cost of equity capital: The initiation of corporate social responsibility reporting. The Accounting Review, 86(1), 59-100.

Dichev, I. D., \& Skinner, D. J. (2002). Large-sample evidence on the debt covenant hypothesis. Journal of Accounting Research, 40(4), 1091-1123.

Dulewicz, V., \& Herbert, P. (2004). Does the composition and practice of boards of directors bear any relationship to the performance of their companies?.

Dvořák, T. (2005). Do domestic investors have an information advantage? Evidence from Indonesia. The Journal of Finance, 60(2), 817-839.

Fink, A., \& Litwin, M. S. (1995). How to measure survey reliability and validity (Vol. 7). Sage.

Francis, J. R. (2004). What do we know about audit quality?. The British accounting review, 36(4), 345-368.

Francis, J. R., \& Krishnan, J. (1999). Accounting accruals and auditor reporting conservatism. Contemporary accounting research, 16(1), 135-165.

Guiral, A. (2011). Corporate Social Performance, Innovation Intensity and Their Impacts on Financial Performance: Evidence from Lending Decision. Innovation Intensity and Their Impacts on Financial Performance: Evidence from Lending Decisions (April 27, 2011).

Guo, F., \& Ma, S. (2015). Ownership characteristics and earnings management in China. The Chinese Economy, 48(5), 372395.

Haryudanto, D., \& Yuyetta, E. N. A. (2011). Effect of earnings management on the level of corporate social responsibility and corporate value. Journal of Accounting and Finance, 3(5), 23-25.

Hassan, O. A., \& Marston, C. (2019). Corporate financial disclosure measurement in the empirical accounting literature: a review article. The International Journal of Accounting, 54(02), 1950006.

Healy, P. M., \& Palepu, K. G. (2001). Information asymmetry, corporate disclosure, and the capital markets: A review of the empirical disclosure literature. Journal of Accounting and Economics, 31(1-3), 405-440.

Hribar, P., \& Collins, D. W. (2002). Errors in estimating accruals: Implications for empirical research. Journal of Accounting Research, 40(1), 105-134.

Ioannou, I., \& Serafeim, G. (2015). The impact of corporate social responsibility on investment recommendations: Analysts' perceptions and shifting institutional logics. Strategic Management Journal, 36(7), 1053-1081.

Jensen, M. C., \& Meckling, W. H. (1976). Jensen, M. C., \& Meckling, W. H. (1976). Theory of the firm: Managerial behavior, agency costs and ownership structure. Journal of Financial Economics, 3(4), 305-360. 
Jones, J. J. (1991). Earnings management during import relief investigations. Journal of accounting research, 29(2), 193228.

Jones, S., \& Hensher, D. A. (2007). Evaluating the behavioural performance of alternative logit models: an application to corporate takeovers research. Journal of Business Finance \& Accounting, 34(7-8), 1193-1220.

Kelton, A. S., \& Yang, Y. W. (2008). The impact of corporate governance on Internet financial reporting. Journal of accounting and Public Policy, 27(1), 62-87.

Kim, Y., Park, M. S., \& Wier, B. (2012). Is earnings quality associated with corporate social responsibility?. The Accounting Review, 87(3), 761-796.

Klein, A. (2002). Audit committee, board of director characteristics, and earnings management. Journal of accounting and economics, 33(3), 375-400.

Laksmana, I., \& Yang, Y. W. (2009). Corporate citizenship and earnings attributes. Advances in Accounting, 25(1), 40-48.

Lang, M., \& Lundholm, R. (1993). Cross-sectional determinants of analyst ratings of corporate disclosures. Journal of Accounting Research, 31(2), 246-271.

Mansfield, E. R., \& Helms, B. P. (1982). Detecting multicollinearity. The American Statistician, 36(3a), 158-160.

Marston, C. L., \& Shrives, P. J. (1991). The use of disclosure indices in accounting research: a review article. The British Accounting Review, 23(3), 195-210.

McWilliams, A., Siegel, D. S., \& Wright, P. M. (2006). Corporate social responsibility: Strategic implications. Journal of management studies, 43 (1), 1-18.

García-Meca, E., \& Sánchez-Ballesta, J. P. (2009). Corporate governance and earnings management: A metaanalysis. Corporate governance: an international review, 17(5), 594-610.

Michelon, G. (2011). Sustainability disclosure and reputation: A comparative study. Corporate reputation review, 14(2), 79-96.

Michelon, G., Pilonato, S., \& Ricceri, F. (2015). CSR reporting practices and the quality of disclosure: An empirical analysis. Critical perspectives on accounting, 33, 59-78.

Murwaningsari, E. (2008). Simultaneous Testing: Some Factors Affecting Earnings Response Coefficient (Erc). In National Symposium on Accounting (Sna) Ke Xi Pontianak (Vol. 23, pp. 1-26).

Muttakin, M. B., Khan, A., \& Azim, M. I. (2015). Corporate social responsibility disclosures and earnings quality. Managerial Auditing Journal.

Ong, T., Trireksani, T., \& Djajadikerta, H. G. (2016). Hard and soft sustainability disclosures: Australia's resources industry. Accounting research journal.

Palanski, M. E., \& Yammarino, F. J. (2007). Integrity and leadership:: clearing the conceptual confusion. European Management Journal, 25(3), 171-184.

Pearce, J. A., \& Zahra, S. A. (1992). Board composition from a strategic contingency perspective. Journal of Management Studies, 29(4), 411-438.

Pham, H. S. T., \& Tran, H. T. (2020). CSR disclosure and firm performance: The mediating role of corporate reputation and moderating role of CEO integrity. Journal of Business Research, 120, 127-136.

Press, E. G., \& Weintrop, J. B. (1990). Accounting-based constraints in public and private debt agreements: Their association with leverage and impact on accounting choice. Journal of accounting and economics, 12(1-3), 65-95.

Prior, D., Surroca, J., \& Tribó, J. A. (2008). Are socially responsible managers really ethical? Exploring the relationship between earnings management and corporate social responsibility. Corporate governance: An international review, 16(3), 160-177.

Rezaee, Z., \& Tuo, L. (2017). Are the Quantity and Quality of Sustainability Disclosures Associated with the Innate and Discretionary Earnings Quality?. Journal of Business Ethics, 1-24.

Roychowdhury, S. (2006). Earnings management through real activities manipulation. Journal of accounting and economics, 42(3), 335-370.

Saidu, S. (2019). CEO characteristics and firm performance: focus on origin, education and ownership. Journal of Global Entrepreneurship Research, 9(1), 1-15.

Salewski, M., \& Zülch, H. (2014). The Association between corporate social responsibility (CSR) and earnings qualityevidence from European blue chips.

Schaltegger, S., Bennett, M., \& Burritt, R. (2006). Sustainability accounting and reporting: development, linkages and reflection. An introduction. In Sustainability accounting and reporting (pp. 1-33). Springer, Dordrecht.

Scott, W. R., \& O'Brien, P. C. (1997). Financial accounting theory (Vol. 3, pp. 335-360). Upper Saddle River, NJ: Prentice hall.

Shleifer, A., \& Vishny, R. W. (1997). 1A Survey of Corporate Governance, mJournal of Finance. Vol: II, (2).

Skinner, D. J., \& Sloan, R. G. (2002). Earnings surprises, growth expectations, and stock returns or don't let an earnings torpedo sink your portfolio. Review of Accounting Studies, 7(2), 289-312.

Sun, L., \& Rath, S. (2010). Earnings management research: a review of contemporary research methods. Global Review of accounting and Finance, 1(1), 121-135.

Sutantoputra, A. W. (2009). Social disclosure rating system for assessing firms' CSR reports. Corporate Communications: An International Journal.

Sweeney, A. P. (1994). Debt-covenant violations and managers' accounting responses. Journal of accounting and Economics, 17(3), 281-308. 
Van Thanh, P., \& Podruzsik, S. (2018). CSR in Developing Countries: Case Study in Vietnam. Management (18544223), 13(4).

Wang, X., Cao, F., \& Ye, K. (2018). Mandatory corporate social responsibility (CSR) reporting and financial reporting quality: Evidence from a quasi-natural experiment. Journal of Business Ethics, 152(1), 253-274.

Ward, H. (2004). Public sector roles in strengthening corporate social responsibility: taking stock. Washington, DC: World Bank.

Warfield, T. D., Wild, J. J., \& Wild, K. L. (1995). Managerial ownership, accounting choices, and informativeness of earnings. Journal of accounting and economics, 20(1), 61-91.

World Bank (2020). Doing business in Vietnam $2020 . \quad$ at https://www.doingbusiness.org/content/dam/doingBusiness/country/v/vietnam/VNM.pdf

Yip, E., Van Staden, C., \& Cahan, S. (2011). CSR reporting and EM: The role of political costs. Australasian Accounting Business and Finance Journal, 5(3), 17-33.

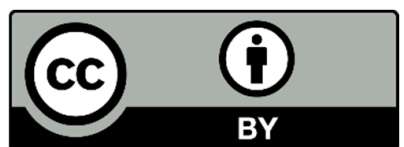

(C) 2022 by the authors; licensee Growing Science, Canada. This is an open access article distributed under the terms and conditions of the Creative Commons Attribution (CC-BY) license (http://creativecommons.org/licenses/by/4.0/). 